\title{
Sosyal Korumada Küresel Boyutlar: Sorunlar ve Temel Tartışmalar
}

\author{
Global Dimensions in Social Protection: Problems and Main Discussions
}

\author{
ABDULKADİR ŞENKAL* \\ * Prof. Dr, Kocaeli University, FEAS, Labor Economics and Industrial Relations, Umuttepe Campus, 41001, \\ İzmit-Kocaeli, Turkey, E-mail: asenkal@kocaeli.edu.tr \\ (D) https://orcid.org/000-0001-5888-7474
}

Öz: Küreselleşme, diğer faktörlerin yanı sıra hızlı teknoloji transferleri, hızl yatırım temposu ve küresel bilgi erişimi ile tetiklenen daha yüksek büyüme, istihdam seviyeleri, yaşam standartları ve sosyal koruma için potansiyel olarak geliştirilmiş mali açıdan kayda değer bir pozitif potansiyele sahiptir. Bununla birlikte, faydaları ülkeler içinde ve arasında eşit olmayan bir şekilde dağılmıştır. Bu durum hem gelişmiş ve hem de gelişmekte olan ülkeler açısından ciddi sorunlar ortaya çıkarmaktadır. Dolayısıyla sosyal koruma, küreselleşme sürecinde ciddi açıklara neden olan bir kavramdır. Yirminci yüzyılın başlarında Batı ülkeleri tarafindan yeni sosyal koruma programlar benimsenmeye başlandıkça toplumsal refaha olan ihtiyacın kapsam ve önemi daha fazla tartışılır hale gelmiştir. Bu tartışmalar, II. Dünya Savaşı'ndan sonraki yıllarda yoğunlaşmış ve hem gelişmiş hem de gelişmekte olan ülkelerde yaygınlaşarak fonlama, hedefler, yönetim ve kapsamı etkileyen konular şeklinde ortaya çıkmıştır.

Anahtar kelimeler: Sosyal koruma, Küresel sosyal koruma, Sosyal politika, Yoksulluk, Küresel sosyal politika

Abstract: Globalization has significant financial positive potential for higher growth, employment levels, living standards and social protection, triggered by rapid technology transfers, rapid investment pace and global information access, among other factors. However, its benefits are unevenly distributed within and between countries. This situation creates serious problems for both developed and developing countries. Therefore, social protection is a concept that causes serious deficits in the globalization process. At the beginning of the twentieth century, as new social protection programs began to be adopted by Western countries, the scope and importance of the need for social welfare became more debatable. These discussions intensified in the years after World War II and became widespread in both developed and developing countries, emerging in the form of issues affecting funding, targets, management and scope.

Keywords: Social protection, Global social protection, Social policy, Poverty, Global social policy 


\section{Giriş}

Sosyal koruma, ekonomik, sosyal, kültürel ve politik ilişkilerin giderek küreselleşmesi ile birlikte ortaya çıkan ve mevcut küreselleşme sürecinde ciddi açılara neden olan bir kavramdır. Yirminci yüzyılın başlarında batı ülkeleri tarafından yeni sosyal koruma programları benimsenmeye başlandıkça toplumsal refaha olan ihtiyacın kapsam ve önemi daha fazla tartışılır hale gelmiştir. Bu tartışmalar, II. Dünya Savaşı'ndan sonraki yıllarda yoğunlaşmış ve hem gelişmiş hem de gelişmekte olan ülkelerde yaygınlaşarak fonlama, hedefler, yönetim ve kapsamı etkileyen konular şeklinde ortaya çıkmıştır.

Sosyal koruma önlemleri, insanları hastalık, malullük veya yaşlılık yoluyla yoksulluğa ve ekonomik kayıplara veya gelir eksikliğine karşı korumak için bir güvenlik ağı sağlamayı amaçlamaktadır. Dünya nüfusunun yalnızca dörtte birinin sosyal korumaya erişimi olduğundan bunun yaygınlaştırılması için uluslararası tartışmalar yoğunluk kazanmıştır. Tartışmalarda, ister yoksul gruplara yönelik olsun ya da olmasın, sosyal korumayı küresel düzeyde en iyi nasıl tasarlandığına, kimin yararlanacağı ve finanse edeceği üzerine yoğunlaşmaktadır.

$\mathrm{Bu}$ makale sosyal koruma konusunda son yıllarda büyüyen literatürü gözden geçirmektedir. Yeni olmayan bu kavram son yıllarda önemli ölçüde gelişmiştir. Kavrama çok sayıda perspektiften yaklaşılmakta ve daha geniş literatürle, özellikle kamu politikası, yoksul yanlısı büyüme, haklar, insani yardım stratejilerinin etkinliği incelenmektedir.

\section{Sosyal Koruma: Teorik ve Kavramsal Çerçeve}

Sosyal koruma, 1990'lardan sonra gelişmekte olan ülkelerde yoksullukla mücadele için kullanılan bir politika çerçevesi olarak ortaya çıkmıştır. 1980’li yıllardan sonra Latin Amerika'da artan yoksulluk ve kırılganlık, Asya'da 1997 yılında yaşanan finansal krizler ve geçiş ekonomilerindeki hızlı ekonomik dönüşüm, yoksulluğun ve kırılganlığın azaltılması için güçlü ve istikrarlı kurumlar kurulması gerektiğini göstermiştir. ${ }^{1}$ Bu çerçevede son yirmi yılda başta gelişmekte olan ülkeler olmak üzere bütün dünyada sosyal koruma uygulamaları hızlı bir ilerleme kaydetmiş ve milyonlarca insana fayda sağlamıştır. ${ }^{2}$ Özellikle sosyal korumanın, gelişmekte olan ülkelerdeki yoksulluk ve savunmasızlıklara etkili bir tepki yarattığı, ekonomik ve sosyal kalkınma stratejilerinin önemli bir bileşeni olduğu konusunda artan bir görüş birliği vardır. ${ }^{3}$ Bir dizi faktör, sosyal korumanın önemini arttırdığını göstermektedir. Uluslararası kalkınma örgütleri, özellikle Birleşmiş Milletler'e bağlı ajanslar, sosyal koruma stratejilerini ve politikalarını benimsemiş ve uyarlamıştır. ${ }^{4}$ Ancak birçok gelişmekte olan ülkede sosyal korumanın yaygınlaştırılması ve yeniden tanımlanması, karmaşık konuları ortaya çıkarmaktadır. Sosyal koruma temel olarak, "bir ülkede toplumsal açıdan kabul edilmeyen kırllganlık, risk ve yoksulluk düzeylerine yanıt olarak alınan kamu eylemlerini" tanımlayan bir politika çerçevesi olarak anlaşılmıştır. ${ }^{5}$

\footnotetext{
${ }^{1}$ Abdulkadir Şenkal, Yoksulluğun Politik Ekonomisi, Ankara: Nobel Akademik Yayınc1lık, 2021, s.283.

${ }^{2}$ Sarah K. Lowder, Raffaele Bertini ve André Croppenstedt, "Poverty, Social Protection and Agriculture: Levels and Trends in Data”, Global Food Security, 15 (2017), s.96.

${ }^{3}$ Armando Barrientos ve David Hulme, "Social Protection for the Poor and Poorest in Developing Countries: Reflections on a Quiet Revolution Commentary", Oxford Development Studies, 37/4 (2009), s.423.

${ }^{4}$ Armando Barrientos, "Social Protection and Poverty", International Journal of Social Welfare, (Special Issue: Social policy and poverty), 20/3 (2011), s.242.

${ }^{5}$ Tim Conway, Arjan de Haan ve Andy Norton, "Social Protection: New Directions of Donor Agencies",
} 
Sosyal güvenlik ve sosyal koruma sınırlarının kalkınma bağlamında tanımları ve yorumları, akademisyenler ve uluslararası kuruluşlar arasında çeşitlilik göstermektedir. Literatürde sosyal koruma, sosyal güvenlikten çok daha geniş ve daha kapsayıcı olarak yorumlanmaktadır. Çünkü sosyal güvenlik özel tedbirler hatta yasal olmayan tedbirler içermektedir. Ancak yine de sosyal yardım ve sosyal sigorta gibi geleneksel sosyal güvenlik önlemlerini kapsamaktadır. ${ }^{6}$ ILO sosyal korumayı, toplum içerisinde insanların beklenmedik durumlar (Hastalık, Analık, İş Kazası, İşsizlik, Malullük, Yaşlılık ve Anne-Babanın ölümü) nedeniyle gelirlerinde meydana gelen azalma veya gelir kaybından kaynaklanan ekonomik ve sosyal sıkıntılara karşı bireyleri koruyan, sağlık hizmetleri ve yardım temin eden bir dizi kamu önlemi olarak tanımlar. Ancak gelişim açısından önemine rağmen eğitimin bu tanıma dâhil edilmediği dikkat çekicidir.

Sosyal koruma, geleneksel olarak, hastalık, işsizlik veya ekonomik kriz gibi beklenmedik durumlarla karşılaşıldığında insanları veya hanehalklarını gelir yetersizliğinden veya yoksulluktan korumak için kullanılan bir politika aracıdır. Bu açıdan sosyal koruma, 20. yüzyılın en önemli sosyal başarılarından biri olarak kabul edilebilir. Çoğu sosyal koruma sistemi, II. Dünya Savaşı'ndan sonra gelişmiş ekonomilerde oluşturulmuş ve yaygınlaştırılmıştır. Birçoğu, istihdam ilişkisinin ve özellikle açı uçlu sözleşmenin bir parçası olarak mali katkılarla desteklenmek üzere inşa edilmiştir. Bu nedenle, (mali) temelleri ve iş durumları genellikle farklı işgücü piyasalarına ve sosyal yapılara dayanmaktadır. Sosyal koruma sistemleri düzgün bir yaşam sürdürebilmek için vatandaşları kırılganlıktan koruyarak refahını ve güvenliğini geliştirmesini sağlar. Bir yandan, sosyal koruma, vatandaşların sosyal ve ekonomik güvenceye sahip olmasını sağlayarak insanların hayatta kalmaları için temel ihtiyaçlarını karşılarken öte yandan bireylerin ve toplumların yaşam kalitesinin arttırılmasında daha geniş kapsamlı bir rol oynayabilir. Bu sayede insanların potansiyelini geliştirmek ve açığa çıkarmak, istikrarı artırmak, sosyal adaleti sağlamak ve ekonomik dinamizmi teşvik etmek için ortam sağlamaktadır.

Genel olarak, sosyal korumanın üç geniş bileşeni-transferler, sigorta ve sosyal hizmetler-toplumda dezavantajlı, ötekileştirilmiş veya savunmasız kişilerin statüsünü güçlendirmek ve geliştirmek için sıklıkla haklar ve mevzuat dâhil olmak üzere dördüncü bir sütunla desteklenir. ${ }^{7}$ Yine de, prensipte sosyal korumanın önemi konusunda fikir birliği olmasına rağmen, kavramsal sınırları ve pratik tanımlar farklı yorumlara açıktır. Gerçekte, sosyal korumanın mantığı, kapsamı, hedefleri ve bileşimi üzerine çok çeşitli yaklaşımlar vardır. Bu tür bir çeşitlilik, hem kavramsal olarak kapsamlı hem de teknik olarak ilgili olan ortak tanımların geliştirilmesini zorlaştırmaktadır. ${ }^{8}$

Sosyal koruma, hastalık, iş kaybı veya ekonomik krizin etkisi gibi beklenmedik durumlarla karşılaşıldığında insanları veya hanehalklarını gelir yetersizliğinden veya yoksulluktan korumak için geleneksel olarak kullanılan bir politika aracıdır. Genellikle, sosyal koruma, belli bir toplumdaki insanlar arasındaki yoksulluk, risk ve

Research Report, London: Department for International Development (ODI), 2000, s.34.

${ }^{6}$ A. Bonilla-Garcia ve J. V. Gruat, Social Protection: A Life Cycle Continuum Investment for Social Justice, Poverty Reduction and Sustainable Development, Geneva: ILO, 2003, s.73.

${ }^{7}$ Ugo Gentilini, Steven Were Omamo, "Social Protection 2.0: Exploring Issues, Evidence and Debates in a Globalizing World”, Food Policy, 36/3 (2011), s.332.

${ }^{8}$ Srawooth Paitoonpong, Shigeyuki Abe ve Nipon Puopongsakorn, The Meaning of 'Social Safety Nets", Journal of Asian Economics, 19/5-6 (2008), s.468. 
savunmasızlığı hafifletmek için tasarlanmış kamu ve gönüllü tedbirler ve programlar sistemi olarak anlaşılabilir. Bu tanım, yoksulluğun, sosyal risklerin ve güvenlik açıklarının çeşitlilik gösterdiğini, bu nedenle bazı entegre önlemler gerektirdiğini belirtmektedir. ${ }^{9}$

Ülkeler arasında giderek artan eşitsizliklerle birlikte, sosyal eşitsizliklere karşı güçlü bir devlet politikası olarak sosyal adalet ve insan haklarına dayanan sosyal koruma politikalarına ihtiyaç duyulmaktadır. ${ }^{10}$ Gelişmiş ülkelerde, sosyal koruma, sosyal sigorta, sosyal yardım ve istihdam korunması gibi bir dizi entegre kurum ve programdan oluşur. 1990'ların başlarından beri ve ekonomik krizler, yapısal uyum ve küreselleşmenin gelişimi ile birlikte sosyal koruma, gelişmekte olan ülkelerde gittikçe farklı bir politika gündemi olarak tanımlanmıştır. Bu süreçte ortaya çıkan paradigmanın birkaç ayırt edici özelliği vardır. Gelişmekte olan ülkelerde, sosyal koruma yoksullar üzerine yoğun bir şekilde odaklanmaktadır. Gelişmiş ekonomilerdeki sosyal korumayla karşılaştırıldığında, gelişmekte olan ülkelerde sosyal koruma, çok taraflı ve ikili uluslararası kuruluşlar ve uluslararası sivil toplum kuruluşlarını (STK) kapsamaktadır. ${ }^{11}$

Sosyal koruma, hükümetlerin yoksulluğa verdiği en doğrudan tepkilerden biridir. $\mathrm{Bu}$ programlar, uygun şekilde tasarlandığında ve hedeflendiğinde, yoksul hanelerin gelir ve tüketim eksikliklerinin kapatılmasına yardımcı olur. ${ }^{12}$ Ülkeler, evrensel sosyal koruma kapsamını finanse etmek için birçok seçeneği kullanmıştır. Bu seçeneklerden bazıları;

- Kamu harcamalarının yeniden tahsis edilmesi,

- Doğal kaynakların vergilendirilmesinden elde edilen gelir dâhil olmak üzere vergi gelirlerinin artırılması,

- Borç indirimi veya borç hizmeti kullanmak,

- Sosyal güvenlik kapsamının ve katkılarının genişletilmesidir.

Sosyal koruma da çeşitli şekillerde olabilir. Birinci dereceden bir ayrım olarak, kamuya açı veya özel olarak sağlanabilir. Kamu önlemleri yurt içinde (vergi gelirleri, bütçenin yeniden tahsisi ve ticari/piyasa kredisi yoluyla) veya dışarıdan (bağışçılar tarafından) finanse edilebilir; özel mekanizmalar gayri resmi olarak (yasa veya sözleşmeye dayalı anlaşmalarla desteklenmez, örneğin topluluk paylaşım düzenlemeleri) veya resmi olarak piyasa işlemleri (örneğin sigorta ürünleri) yoluyla sağlanabilir. ${ }^{13}$

\section{Sosyal Korumaya Yo̊nelik İlginin Kaynakları}

1990'lara kadar sosyal koruma, temel olarak kavramın ya varlıklı ulusların sosyal güvenliğiyle ya da formel sektördeki işçiler için katkı sağlayan sosyal sigorta programlarıyla ilişkilendirilmesinden dolayı, kalkınmanın ana akım anlayışlarına göre marjinaldi. Bu alanda faaliyet gösteren en önemli kuruluş olan ILO, sosyal kapsamı

\footnotetext{
${ }^{9}$ Fred Moonga ve Sulina Green, "Risks and Vulnerabilities of Children in Zambia: Mooting Responsive Social Protection Interventions", Social Work, 52/3 (2016), s.4. Doğa Başar Sarnipek, "Yoksullukla Mücadelede Şartlı Nakit Transferleri; İnsan Haklari Açısından Bir Değerlendirme”, Mehmet Akif Ersoy Üniversitesi Sosyal Bilimler Enstitüsü Dergisi, 9/20 (2017), s.98.

${ }^{10}$ Julie L. Drolet (der.), Social Development and Social Work Perspectives on Social Protection, London: Routledge, 2016, s.46.

${ }^{11}$ Barrientos ve Hulme, "Social Protection for the Poor and Poorest in Developing Countries", s.423.

${ }^{12}$ Lowder, Bertini ve Croppenstedt, "Poverty, Social Protection and Agriculture", s.97.

${ }^{13}$ Gentilini ve Omamo, "Social Protection 2.0", s.332.
} 
işçileri kapsayacak şekilde genişletme çabalarını sürdürmüş, ancak kayıt dışı sektördeki nüfusları dâhil etmemişti. Bu arka plana karşı, herkes için temel sosyal koruma tabanlarının garanti altına alınması fikrine dayalı olarak çeşitli öneriler geliştirilmiştir. Aslında, 2012'de ILO, evrensel sosyal korumaya ulaşmak için bir tür yol gösterici çerçeve ortaya koyan 202 sayılı kararı onaylamıştır. İnsanın sosyal güvenlik hakkını yeniden teyit eden tavsiye kararı, yaşam döngüsü boyunca, kapsamlı bir sosyal güvenlik sisteminin temel bir unsuru olarak, temel gelir güvencesi ve ihtiyaç duyan herkes için temel sağlık güvencelerinden oluşan sosyal koruma tabanlarının bir öncelik olarak oluşturulması çağrısında bulunuyor. ${ }^{14}$

Yardımlar, ekonomik risklere karşı koruma sağlamayı, ailelere çocuk yetiştirme maliyetlerinde yardımcı olmayı, insanların emeklilik için tasarruf etmelerini sağlamayı ve yaşlılıkta destek sağlamayı amaçlamaktadır. Temel hedefler, yoksulluğu azaltmak için geliri yeniden dağıtmak ve insanların yaşamları boyunca yaşam standartlarını korumalarına yardımcı olmaktır. Katkısız sosyal güvenliğin ücretli olmayan nüfusu kapsayacak şekilde genişletilmesi fikri hem aşırı derecede pahalı hem de "yoksulluk kültürünü" pekiştirmesi muhtemel görülüyordu. Bu uygulama, 1980’lerin ekonomik liberalleşmesi sırasında daha da ileri götürülmüştür. Dünya Bankası, işçilere yönelik sosyal koruma programlarını ekonomik olarak zararlı ve sosyal olarak adaletsiz olduğu gerekçesiyle reddetmiştir. Yalnızca sosyal açıdan savunmasız nüfusların en yoksulları için ayrılmış güvenlik ağlarını kabul edilebilir olarak görülmüştür. ${ }^{15}$

Genel olarak, sosyal koruma politikaları ilk olarak gelişmekte olan ülkelerde II.Dünya Savaşı'ndan sonra uygulamaya konmuştur. 1952 yılında kabul edilen 102 sayılı ILO Sözleşmesi'ne göre, sosyal koruma, çalışanları sosyal risklerden korumayı amaçlayan sosyal güvenlik politikalarını kapsar. Sözleşme, sosyal güvenliğe dâhil edilmesi gereken dokuz alanı tanımlamaktadır. Bunlar: iş kazası ve meslek hastalıkları, hastalık, analık, sakatlık, yaşlılık, ölüm, aile ve işsizliktir. Ayrıca sağlanacak asgari fayda düzeyini belirler. ${ }^{16}$ II. Dünya Savaşı sırasında ILO, daha geniş bir sosyal koruma vizyonuyla etkileşime girmişti, ancak savaştan sonra, resmi istihdamdaki az sayıdaki işçi için sosyal sigorta ile ilgili tek bir düşünceye geri dönmüştür. Ancak baskılar sonucunda gelişmiş ülkeler, gelişmekte olan ülkelerde kalkınma planlarına destek vermek zorunda kaldılar. 1970'lerde, temel olarak istihdam yaratma, sağlık, eğitim, barınma, suya erişim ve sağlık hizmetlerine yönelik hedeflenmiş yatırımlar ve daha sonra küçük ölçekli tarımsal üretimin desteklenmesi "temel ihtiyaçların" ele alınmasını destekleme stratejisi olarak geliştirilmiştir. $^{17}$

ILO, sosyal güvenliği gelişmekte olan ülkelere yaymak için küresel bir kampanya, olan Sosyal Koruma Tabanı Girişimi başlatma girişiminde bulunmuştur. Birleşmiş Milletler Kalkınma Programı (UNDP), kalkınma politikasında sosyal korumanın hayati rolünün altını çizmiştir. İngiltere'de, Uluslararası Kalkınma Departmanı (DfID) sosyal korumayı politikalarının merkezine yerleştirmiştir. Dünya Bankası,

\footnotetext{
${ }^{14}$ ILO, Universal Social Protection for Human Dignity, Social Justice and Sustainable Development. Geneva: ILO, 2019.

${ }^{15}$ Hickey Sam ve Seekings Jeremy, The Global Politics of Social Protection, WIDER Working Paper 115, 2017, s.5.

${ }^{16}$ François-Xavier Merrien, "Social Protection as Development Policy: A New International Agenda for Action”, International Development Policy, 5/1 (2013), s.92.

${ }^{17}$ ILO, Basic Needs in Danger: A Basic Needs Oriented Development Strategy for Tanzania. Addis Ababa, .1982.
} 
DfID ve Birleşmiş Milletler tarafından veya işbirliği içinde sosyal koruma ve kalkınma temasına odaklanan birkaç büyük uluslararası konferans başlatılmıştır. Küresel Güney'de geliştirilen başarılı sosyal koruma programları- Brezilya ve Güney Afrika sosyal emeklilik planları ve Meksika ve Brezilya'da kurulan şartlı nakit transferleri (ŞNT) gibi- küresel düzeyde programlar olarak benimsenmiştir. ${ }^{18}$

Sosyal güvenlik, İnsan Hakları Evrensel Beyannamesi ve Ekonomik, Sosyal ve Kültürel Haklar Sözleşmesi'nde yer alan bir insan hakkıdır. Devletler, tüm vatandaşlar için asgari düzeyde refah ve sosyal destek sağlamakla yükümlüdür. Sosyal Koruma Katlarının uygulamasına ilişkin ILO-Tavsiye 202 (2012), asgari düzeyde sosyal korumayı bir sosyal güvenlik hakkı olarak tanımlamaktadır. Hükümetler, ulusal sosyal koruma sistemlerini tasarlama ve düzenleme konusunda özgürdür. Ancak 1990'ların sonlarında, ekonomik uyum programlarının performansından duyulan hayal kırıklığı, 1997 Asya ekonomik krizi ve küresel yoksulluğun olumsuz etkilerine dair artan farkındalığın yönlendirdiği baskın paradigma değişmiştir. Böylece sosyal koruma, Milenyum Kalkınma Hedefleri'nin tercih edilen bir aracı haline gelirken, Dünya Bankası sosyal korumayı uluslararası yoksulluğu azaltma stratejilerinin önemli bir bileşeni olarak teşvik etmiştir. ${ }^{19}$

2000’li yılların başından itibaren sosyal koruma programları birçok ülkede gelişmiştir. Uluslararası fikirler ve aktörler reform sürecinde aslında önemli ve aktif rol oynamışlardır; ancak bu katkı politika dönüşümünden çok politika çevirisi veya direk politikanın verilmesi şeklinde olmuştur. Dünya Bankası'nın 21.yüzyılın başında nakit transferini kısmi olarak kullanması reformların aktivite edilmesine katkı sağlamakla birlikte, Afrika ülkelerini 'şartlı nakit transferi' yöntemini uygulama konusunda ikna edememişlerdir. Diğer uluslararası kuruluşlar arasında İngiliz Uluslararası Kalkınma Departmanı (DfID), ${ }^{20}$ Uluslararası Çalışma Örgütü (ILO), Birleşmiş Milletler Uluslararası Çocukların Acil Fonu (UNICEF) ve Help Age International (İngiliz temelli hükümet dışı kuruluş ağı) bulunmaktadır.

\section{Sosyal Koruma Anlayışında Reform: Yeni Sosyal Politika Yaklaşımı}

Uluslararası kalkınma pratiği, sosyal koruma politikası söyleminin yükselişini takiben 1990'lardan sonra yeni bir sosyal politika anlayışı kazanmıştır. Artık uluslararası yardım kuruluşları tarafından bir " $y \ddot{u} k$ ” olarak görülmemektedir. Diğer bir değişle sosyal koruma, gelişmekte olan ülkelerde giderek artan bir şekilde sosyal politika için bir gündem tanımlamaktadır. ${ }^{21}$ Sosyal koruma bir insan hakkıdır ve yüksek sosyal ve ekonomik getirisi olan bir yatırımdır. Ancak dünya nüfusunun yarısından fazlasının herhangi bir sosyal korumaya erişimi yoktur. Çocuklar, engelliler, kayıt dışı ekonomide çalışan kadınlar ve erkekler ve göçmenler gibi savunmasız grupların kapsamı özellikle düşüktür. ${ }^{22}$ Çünkü sosyal politika, yalnızca refah yardımlarının ve sosyal koruma programlarının yeniden dağıtım, sosyal eşitlik ve kapsayıcılık için önemli olmasının sağlanmasıyla ilgili değildir; aynı zamanda hak

\footnotetext{
${ }^{18}$ Merrien, "Social Protection as Development Policy", s.92.

${ }^{19}$ World Bank, Social Protection Sector Strategy: From Safety Net to Springboard, Washington, DC: The World Bank, 2001.

${ }^{20}$ DfID'nin sosyal güvenlik konularındaki ilgisi, 2000’lerin ortalarına doğru yavaşça artmıştır. Sosyal güvenliğe artan ilgi ve uluslararası gelişim dâhilinde bilgilenmiştir. Ama aynı zamanda Afrika'daki ortak ülkeler tarafından gerçekleştirilen politik tartışmalar da DfID’nin bilgilenmesine yardımcı olmuştur.

${ }^{21}$ Hanlon, J. Barrientos ve David. A. Hulme. Just Give Money to the Poor: The Development Revolution from the Global South. Sterling, Vancouver, USA: Kumarian Press, 2010, s.63

${ }^{22}$ ILO, "World Social Protection Report (2017-2019)". 2019 https://www.ilo.org/wcmsp5/groups/public/--dgreports/---dcomm/---publ/documents/publication/wcms_604882.pdf.
} 
talebinde bulunmaya dâhil olan siyasi seferberlik ve bunun sonucunda sosyal organizasyon ve uyumu etkileyen yetkilendirme mekanizmalarıla da ilgilidir. ${ }^{23}$ Sosyal koruma reformları, kapsamlı kurumsal değişim süreçlerini içerir. Dinamikler, sosyal koruma direkleri boyunca sadece ülkeler arasında değil, ülkeler içinde de farklılık göstermektedir. Entegre ulusal sosyal koruma sistemlerini geliştirmek için, tek tek araçların izole görünümünden uzaklaşarak, farklı alt politika alanlarındaki reform dinamiklerinin karşılaştırmalı bir anlayışına doğru hareket etmek önemlidir.

Gelişmekte olan ülkelerdeki sosyal koruma, artık ekonomik krizleri iyileştirmenin kısa vadeli bir yolu olarak değil, aşırı derecede savunmasız gruplar için nakit transfer programlarını birleştiren küresel bir politika olarak, sosyal bir yatırım perspektifini sosyal transferle birleştiren yeni programlar olarak algılanmaktadır. ${ }^{24}$ Sosyal koruma basit bir teknik mesele değildir, ancak giderek daha mantıklı politikaların oluşturulmasını mümkün kılmak için sosyal öğrenmenin aşamalı olarak uygulanmasını gerektirir. ${ }^{25}$ Sosyal koruma, bazı ülkelerde ve kurumlarda hala tartışma konusudur. Genel olarak, söylem, sosyal güvensizlik konularının değerlendirildiği ve politika tepkilerinin tasarlandığı, nispeten tutarlı bir değerler kümesini ve istikrarlı bir analitik çerçeveyi yansıtmaktadır. ${ }^{26}$

Sosyal politikanın, gelişmekte olan ülkeler için maliyetli bir uygulama olduğu veya düşük gelirli bağlamlarla uyumsuz olduğu düşünüldügünden, yakın zamana kadar kalkınma söyleminde pek gündemde değildi. Yoksulluğun azaltılması açısından neoliberal politikaların olumsuz sonuçları ve eşitsizlik, 1990'lardan beri kalkınma stratejisinin ana bileşeni olarak sosyal politikanın geri dönüşünü kolaylaştırmıştır. $\mathrm{Bu}$ sürecin sonucu olarak kamu sektörünün daralması, serbest piyasa, neoliberal devlet ve hedefleme yaklaşımı, geri dönen sosyal politikanın temel özellikleriydi ve yoksulluğun azaltılması üzerinde olumsuz bir etkisi olmuştur. ${ }^{27}$

Evrensel sosyal korumaya ulaşmak, devletin programları ve kurumları oluşturma, finanse etme, yönetme ve düzenleme konusunda temel sorumlulukları üstlenmesini gerektirir ${ }^{28}$. Ancak gerçek, yoksul ülkelerdeki en yoksul hanelerin akraba, cemaat ve dini kurumlar gibi devlet dışı kaynaklara güvendiğini ve nadiren doğrudan devlet desteğinden yararlandığını göstermektedir. ${ }^{29}$ Sosyal korumanın, sosyal güvenlik ve sosyal hizmet adına sosyal politikanın evrimini gözden geçirmesinden, yalnızca koruyucu bir önlem olmadığını, aynı zamanda üretime, yeniden dağıtıma, korumaya ve korumaya müdahale eden bir dizi kamu politikası olduğunu kabul edilebilir. Özellikle yeniden üretim ve ekonomik büyümeyi kolaylaştırmanın yanı sıra yoksulluk ve eşitsizlikle mücadelede kritik bir rol oynamıştır. Sonuç olarak

\footnotetext{
${ }^{23}$ Nanna Kildal ve Stein Kuhnle (2006), Normative Foundations of the Welfare State: The Nordic Experience, London: Routledge, 2006, s.31.

${ }^{24}$ Merrien, "Social Protection as Development Policy", s.93.

${ }^{25}$ Armando Barrientos ve David Hulme, Social Protection for the Poor and the Poorest: Concept, Policies and Politics, Basingstoke: Palgrave Macmillan, 2008, s.74.

${ }^{26}$ François-Xavier Merrien ve Angèle Flora Mendy, "International Organizations”, The Human Economy, der., Keith Hart, Jean-Louis Laville ve Antonio David Cattani. Cambridge: Polity Press, 2010, s.42.

${ }^{27}$ Yi Ilcheong, "Social Protection, Social Security and Social Service in a Development Context: Transformative Social Policy Approach", Journal of International Development Cooperation, 4 (2010), s.58.

${ }^{28}$ UNRISD, Combating Poverty and Inequality: Structural Change, Social Policy and Politics, Geneva, Switzerland, 2010.

${ }^{29}$ Andy Norton, Tim Conway ve Mick Foster, "Social Protection Concepts and Approaches: Implications for Policy and Practice in International Development", Working Paper no. 143, Centre for Aid and Public Expenditure. London: Overseas Development Institute 2001, s.7.
} 
yoksulluğu ve eşitsizliği azaltabilecek sosyal dönüşüm için geniş bir politika çerçevesi içinde anlaşılmış, özel olarak yoksulluğu hedefleyen bir politika çerçevesi (sosyal koruma) yerine tasarlanmış ve uygulanmıştır.

Sosyal koruma ve sosyal güvenlik ile ilgili politikalardan biri, yeniden dağıtımın yanı sıra yoksullukla mücadele stratejisinin temel bileşeni olduğu ve evrensel kapsama ulaşmanın ancak devletin üretime müdahalesi ile gerçekleştirilebileceğidir. Yoksulluğu ve eşitsizliği azaltmak için sosyal politikaya kapsamlı ve bütünsel yaklaşımın önemini yeniden teyit etmektedir. Evrensellik ilkesine dayanan dönüştürücü sosyal politika yaklaşımı üretim, yeniden dağıtım, koruma ve yeniden üretim gibi toplumun tüm temel işlevlerine, gelişmekte olan ülkelerde mevcut hâkim sosyal politika, özelleştirme ve hedefleme yaklaşımının sorunlarını ele alabilecek tek yaklaşım olacaktır. ${ }^{30}$

Sosyal koruma yardımlarının evrenselleştirilmesine yönelik kısmi ilerlemeler, yukarıda bahsedilen tarihsel engellerle ve ters yönde ilerleyen yeni eğilimlerle birleşiyor. Bu anlamda, mevcut üç zorluktan bahsetmeye değer. İlk olarak, temel sosyal altyapıyı inşa etmek ve hatta hizmet sunumu için kamu-özel sektör ortaklıklarının teşviki dâhil olmak üzere eğitim ve sağlık alanlarında sosyal korumayı özelleştirme eğilimidir.

İkincisi, maliye politikalarında sosyal korumaya yönelik fonlamayı baltalayan kemer sıkma paradigmasıdır. Küresel Güney'deki pek çok ülke bazı kaçınılmaz durum kombinasyonuyla karşı karşıyadır: özellikle büyük şirketler ve ulusötesi şirketler çeşitli vergi kaçırma ve vergi istismarı mekanizmaları kullandıkları için çok az fon toplayan ve gerileyen vergi yapıları mevcuttur. Sonuç olarak, mali açıklar, kemer sıkma önlemleri ve borçlanma ile karşılanmakta, bu önlemler sosyal risklerden kaynaklanan talepleri karşılamak için özelleştirme ve/veya özel sektörden fon toplama yoluna gidilmesi önemli bir sorundur. Üçüncüsü, vergiye dayalı sosyal koruma sistemlerinin temeli olan olağan resmi ücretli "kayıtli" işten giderek uzaklaşan "çalışmanın geleceği” istihdam biçimlerinin getirdiği zorluklardır. Tersine, üretimin artan âdemi merkezileşmesi, uzaktan çalışma ile birlikte yeni teknolojiler aracılığıyla sağlanan istihdam biçimleri, çalışma ilişkilerini bozmaya ve işçileri giderek daha fazla sosyal koruma eksikliği durumlarına yöneltmeye başlamaktadır. ${ }^{31}$

\section{Sosyal Korumanın Yeniden Gündeme Gelişis: Yerelden Küresele Yeni Eğilimler}

Sosyal koruma yeni bir kavram değildir. Esasen, toplumların zengin bireylerden vergi toplayarak zor zamanlarında ihtiyacı olanları nasıl desteklediklerimi açıklar. Yüzyıllar boyunca sosyal koruma, ekonomiler piyasa odaklı ve birbiriyle bağlantılı hale geldikçe, ülkelerin sosyal sözleşmelerinin temel ilkelerinden biri olmuştur. Daha yakın zamanlarda, bu kavrama makroekonomik istikrar sağlayıcıdan insani müdahalelere yani risk yönetiminden sosyal adaleti teşvik etmeye kadar geniş bir perspektif yelpazesinden yaklaşılmıştır. Ortaya çıkan genel çerçeve, diğerlerinin yanı sıra kamu politikaları, kalkınma stratejileri ve yardım etkinliği etrafında daha geniş geleneksel tartışmaları keserek yardım, sigorta ve sosyal dönüşümü kapsayan

\footnotetext{
${ }^{30}$ Ilcheong, "Social Protection, Social Security and Social Service in a Development Context", s.58.

${ }^{31}$ Rodríguez Enríquez Corina, "Current Challenges and Debates on Social Protection in the Global South", Development Alternatives with Women for a New Era (DAWN) sitesi, March 19, 2020, https://dawnnet.org/2020/03/social-protection-in-the-global-south/.
} 
çoklu hedeflere işaret etmektedir. ${ }^{32}$ Aynı zamanda, sosyal koruma konusundaki tartışmalar da giderek küresel bir önem kazanmaktadır. OECD ülkeleri refah reformunda önemli zorluklarla karşı karşıyayken, yükselen ekonomiler küresel sosyal koruma gündemini şekillendirmede büyüyen bir rol oynamaktadır. Kapsamlı sistemlerin kurulması halen devam etmekte olsa da Brezilya, Çin, Meksika ve Güney Afrika gibi ülkeler proaktif politika modellerini denemekte, genişletmekte ve onlara meydan okumaktadır. Dolayısıyla sosyal korumada yeni inovasyon kutupları olarak ortaya çıkmaktadırlar. ${ }^{33}$ Ayrıca, düşük gelirli ülkelerde de sosyal korumanın önemi hızla artmaktadır. Özellikle, Afrika ve Asya'daki pek çok bağlamda sosyal koruma, yardım ve kalkınma yaklaşımlarını uzlaştırmak, hak temelli girişimleri savunmak ve pilot programlardan entegre sistemlere geçmeye yardımcı olmak için uzun süredir devam eden tartışmaları yeniden canlandırmaktadır.

Sosyal korumanın yükselişinin ardındaki başlıca küresel itici güçler, krizlerin, yoksulluk ve kısa vadeli güvenlik ağlarının etkisizliği ile birlikte küreselleşmiş bir dünyanın, sosyal korumaya sahip olmaması ile ilişkili büyük maliyetleri ifade ettiğini bu yüzden Binyıl Kalkınma Hedefleri'ni getiren yoksulluğun azaltılması konusundaki uluslararası ilgiydi. $\mathrm{Bu}$, bölgesel ve alt-bölgesel düzeylerde sosyal korumanın uzatılmasında stilize yollarla ilgili bir tartışma ile tamamlanmıştır. Tartışma, önceden varolan kurumlardan, ekonomik kalkınma ve sosyal ve ekonomik dönüşüm özelliklerinden etkilenen sosyal koruma yanıtlarının çeşitliliğini ortaya koymuştur. Özellikle düşük gelirli ülkelerde gelecekte sosyal korumanın gidişatı büyük ölçüde üç faktör tarafından belirlenecektir. Birincisi, ulus devlet kurumları tarafından yönetilen ve ulusal sosyal koruma stratejilerini destekleyen geniş ortaklıkların güçlendirilmesidir. İkincisi, orta ve uzun vadede finansman kısıtlamalarını azaltmak için yenilikçi yollar bulmakta başarı sağlanmasıdır. Bu, gelişmekte olan ülkelerde gelir seferberliğini güçlendirmeyi kapsamaktadır. Üçüncüsü, sosyal koruma talebini güçlendirmektir. ${ }^{34}$

Son olarak araştırmacıların ve politikacıların odaklanması gereken iki önemli bilgi sorgulanmaktadır. Birincisi, başarılı sosyal koruma programlarının düşük gelirli ülkelerde ulusal seviyeye yükseltilmesinin yollarını bulmak zaten bir öncelik ve bunun devam etmesi gereklidir. İkincisi, kırılgan ülkelerdeki sosyal koruma programları ve zorlu ortamlar hakkında montaj deneyleri ve pilot programlar yoluyla bilgi üretmek ihmal edilmiştir. Sosyal koruma, kırılgan ülkelerde yaşayan insanların umutsuz, acil ihtiyaçlarını karşılama, aynı zamanda barış inşası çabalarını destekleme ve milislerin hareketsiz kılınmasını destekleme yeteneğine sahip olabilir.

\section{Yerelden Kürresele Dönüşüm}

Evrensel sosyal koruma, herkes için sosyal güvenlik hakkını gerçekleştirmek, sosyal adaleti ilerletmek, kapsayıcı büyümeyi teşvik etmek ve küresel olarak kabul edilmiş Sürdürülebilir Kalkınma Hedefleri'ne ulaşma yolunda ilerlemeyi hızlandırmak için gereklidir. ${ }^{35}$ Birçok hükümet, yıllar boyunca sosyal korumayla ilgili uluslararası

\footnotetext{
${ }^{32}$ Gentilini ve Omamo, "Social Protection 2.0”, s.332.

${ }^{33}$ Devereux, Stephen. "Building Social Protection System in Southern Africa". Background Paper to the European Report on Development, Center for Protection, Institute of Development Studies, Brighton, 2010, s.8.

${ }^{34}$ Sakiko Fukuda-Parr, "Millennium Development Goal 8: Indicators for International Human Rights Obligations?” Human Rights Quarterly, 28 (2006), s.972.

${ }^{35}$ ILO, "World Social Protection Report (2017-2019)", 2017, https://16dayscampaign.org/resource/ilo-worldsocial-protection-report-2017-2019/.
} 
antlaşma ve sözleşmeler imzalamış olsa da, son zamanlarda sadece sosyal koruma ile ilgili tartışmalar küresel düzeyde gerçekleşmiştir. Daha önce, alanda çalışan akademisyenler ve politikacılar büyük ölçüde iç meselelere odaklanmış ve karşılaştırmalı çalışmalar bile belirli ülkelerin sosyal koruma sistemlerini belgelemekle sınırlıydı. Bugün, sosyal koruma giderek küresel eğilimlerle ve ILO Sözleşmeleri, İnsan Hakları Evrensel Beyannamesi ve Binyıl Kalkınma Hedefleri doğrultusunda uluslararası olarak üzerinde anlaşmaya varılan hedefleri yerine getirmekle ilgilenmektedir. Bu, ulusal hükümetlerin taahhütlerini aşan daha geniş bir küresel odağı yansıtmaktadır. İnsanlık ilk defa sahip olduklarını ve refahı artıracak hedeflere ulaşmak için bir taahhütte bulunmuştur. Çiçek hastalığının başarılı bir şekilde ortadan kaldırılması gibi daha önceki uluslararası çabalar, yoksulluk, açlık, anne ölümleri, okur-yazarlık ve insan durumunu karakterize eden diğer hastalıklarla mücadele için iddialı bir görev üzerinde küresel işbirliğinin yolunu açmıştır. ${ }^{36} \mathrm{Bu}$ dönüşümdeki kilit nokta, bireye ve insanların (çalışma) yaşamları boyunca deneyimledikleri değişen ihtiyaçlara daha iyi uyarlanmış sosyal korumanın geliştirilmesidir.

Sosyal koruma, Binyıl Kalkınma Hedefleri'ne resmi olarak dâhil edilmemiş, ancak ILO ve Birleşmiş Milletler gibi uluslararası kuruluşlar, herkesin kapsam alanını genişletmek için benzer bir çabayı göstermişlerdir. Birçok hükümet, tüm kampanyalar için sosyal güvenliğe imza atmış ve evrensel sosyal güvenlik katının oluşturulmasını desteklediği için, sosyal korumanın genişletilmesi için bir ivme oluşmaktadir.

\section{Dönüşüimü Boyutları: Evrensel veya Hedefe Yönelik Koruma}

1990’lardan sonra sosyal koruma alanında önemli bir entelektüel ortam ortaya çıkmıştır. Bu entelektüel girişimler esas olarak Sahra-altı Afrika, Latin Amerika ve Güney Doğu Asya'da çalışan uluslararası kalkınma akademisyenleri tarafından yönetilen, sosyal koruma teorisinin 'birinci nesli' olarak adlandırılır. Bu literatür, aşağıdakiler de dahil olmak üzere çok çeşitli anlamlar ve politika atıfları biriktirmiştir: (1) yoksullara ve aşırı yoksullara odaklanarak sosyal risklere karşı koruma; insan haklarının veya geçim kaynaklarının teşviki; Polanyian ölçeğinde kapsamlı sosyal dönüşüm; (2) Uluslararası Çalışma Örgütü'nün (ILO) Sosyal Koruma Tabanı Çerçevesi tarafından savunulduğu gibi, sosyal güvenliğin genişletilmesine kadar geniş bir yelpazeye yayılan ve Dünya Bankası tarafından savunulduğu gibi, hem ulusal sosyal politika hem de insani ortamlarda hedeflenen nakit transfer programlarının teşvikine dayanan kamu müdahalelerinin tamamıdır. ${ }^{37}$

Sosyal korumanın maliyetleri üzerine yapılan analizlerde, sosyal korumanın düşük gelirli ülkelerde bile karşılanabilir olduğu sonucuna varmaktadır. Yine de, sürdürülebilirlikle ilgili bazı sorunlar vardır. Örneğin, tüketim ve doğal kaynakların vergilendirilmesi yoluyla kamu harcamalarını sosyal korumaya kaydırmak ve politik meşruiyetini sürdürmek, şirketler için büyük kayıplar anlamına geliyorsa zordur. Öte yandan, gelir ve vergilendirme yoluyla yeniden dağıtım yaklaşımı, işçilerin çalışma teşviklerini azaltabilir ve piyasa dışı gelirler üzerindeki vergiler, tasarruf teşviklerini azaltabilir.

\footnotetext{
${ }^{36}$ James Midgley, “Social Protection and Social Policy: Key Issues and Debates”, Journal of Policy Practice, 11/1-2 (2012): s.10.

${ }^{37}$ Sam Hickey, “The Politics of Social Protection: What do We Get from a 'Social Contract' Approach?", Canadian Journal of Development, 32/4 (2011), s.429.
} 
Küresel olarak, sosyal koruma, hükümet harcamalarının büyük bir bölümünü (\% 36) temsil etmektedir. Ancak, sosyal koruma harcamalarının yalnızca küçük bir kısmı (\% 10) düşük ve orta gelirli ülkelere atfedilmektedir. Sosyal koruma harcamaları, GSYİH kullanılarak ölçüldügüüne, son on yıllarda önemli ölçüde artmıştır. 2009 yılından bu yana, Sahra-altı Afrika'da harcamalarda hızlı büyüme meydana gelmiş ve bu bölgenin yoğunluğu Doğu Asya ve Pasifik'in üzerine çıkmıştır. ${ }^{38} \mathrm{Bu}$ farklılıklar, tasarımlarından, onlara liderlik eden devletlerin kapasitesinden ve faaliyet gösterdikleri bağlamdan (ekonomik dinamikler, işgücü piyasalarının özellikleri ve cinsiyet rejimleri dâhil sosyal yapılar dâhil) kaynaklanmaktadır. ILO, 2015 yılına kadar dünya nüfusunun ancak \% 45,2'sinin sosyal koruma yardımına erişimi olduğunu belirtmektedir. Ancak bu oran Avrupa ve Orta Asya'da \% 84.1'e yükselirken, Sahra-altı Afrika'da \% 12.9'a düşmektedir. ${ }^{39}$

Tablo 1. Sosyal Korumaya Yönelik Toplam Genel Devlet Harcamaları, 2018 (GSYİH'nin Yüzdesi)

\begin{tabular}{|c|c|c|c|c|c|c|c|c|c|c|}
\hline & 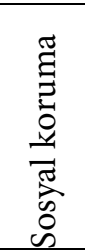 & 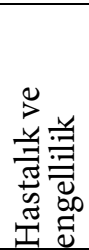 & 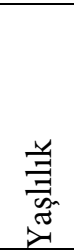 & 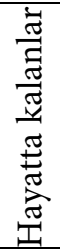 & 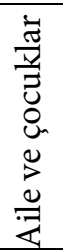 & 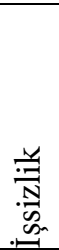 & 空 & 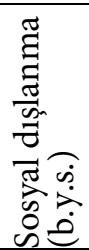 & 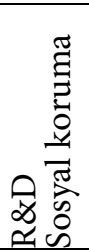 & 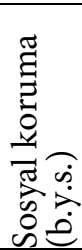 \\
\hline $\mathrm{AB}-27$ & 19.2 & 2.7 & 10.4 & 1.5 & 1.7 & 1.3 & 0.3 & 0.8 & 0.0 & 0.3 \\
\hline AB-28 & 18.6 & 2.7 & 10.1 & 1.3 & 1.7 & 1.2 & 0.4 & 0.9 & 0.0 & 0.3 \\
\hline Avrupa bölgesi & 19.6 & 2.7 & 10.7 & 1.7 & 1.6 & 1.4 & 0.4 & 0.8 & 0.0 & 0.3 \\
\hline Belçika & 19.3 & 3.3 & 9.2 & 1.6 & 2.2 & 1.5 & 0.2 & 1.1 . & 0.0 & 0.1 \\
\hline Bulgaristan & 12.0 & 0.3 & 8.9 & - & 2.3 & 0.1 & 0.1 & 0.1 & - & 0.4 \\
\hline Çekya & 12.0 & 2.2 . & 7.4 & 0.5 & 1.1 . & 0.1 & 0.2 & 0.4 & 0.0 & 0.2 \\
\hline Danimarka & 21.9 & 4.4 & & & & & & & 0.0 & \\
\hline Almanya & 19.4 & 3.2 & 9.5 & 1.9 & 1.7 & 1.5 & 0.4 & 0.6 & 0.0 & 0.7 \\
\hline Estonya & 13.0 & 2.1 & 6.7 & 0.1 & 2.7 & 1.2 & 0.0 & 0.2 & 0.0 & 0.1 \\
\hline İrlanda & 9.0 & 1.8 & 3.2 & 0.6 & 1.3 & 0.9 & 0.9 & 0.3 & 0.0 & 0.0 \\
\hline Yunanistan & 19.0 & 1.5 & 13.2 & 2.0 & 0.8 & 0.5 & 0.0 & 0.9 & 0.0 & 0.0 \\
\hline İspanya & 16.9 & 2.4 & 9.4 & 2.2 & 0.8 & 1.6 & 0.0 & 0.3 & 0.0 & 0.1 \\
\hline Fransa & 23.9 & 2.9 & 13.3 & 1.5 & 2.2 & 1.9 & 0.9 & 1.1 & 0.0 & 0.2 \\
\hline Hirvatistan & 14.7 & 2.3 & 8.0 & 1.3 & 1.9 & 0.5 & 0.0 & 0.1 & 0.0 & 0.6 \\
\hline İtalya & 20.8 & 1.8 & 13.3 & 2.6 & 1.0 & 1.1 & 0.0 & 0.9 & 0.0 & 0.1 \\
\hline Kibris & 12.5 & 0.5 & 6.1 & 1.4 & 2.8 & 0.5 & 0.0 & 1.1 & 0.0 & 0.1 \\
\hline Letonya & 11.6 & 2.2 & 6.8 & 0.2 & 1.3 & 0.5 & 0.1 & 0.4 & 0.0 & 0.3 \\
\hline Litvanya & 12.1 & 3.0 & 6.2 & 0.3 & 1.5 & 0.6 & 0.1 & 0.3 & 0.0 & 0.2 \\
\hline Lüksemburg & 18.0 & 3.0 & 9.5 & 0.0 & 3.6 & 1.0 & 0.1 & 0.7 & 0.0 & 0.1 \\
\hline Macaristan & 13.3 & 2.8 & 6.7 & 0.9 & 1.7 & 0.3 & 0.1 & 0.8 & 0.0 & 0.2 \\
\hline Malta & 10.9 & 0.9 & 6.7 & 1.3 & 0.9 & 0.2 & 0.1 & 0.8 & 0.0 & 0.2 \\
\hline Hollanda & 15.5 & 4.1 & 6.4 & 0.1 & 1.4 & 1.4 & 0.5 & 1.6 & 0.0 & 0.0 \\
\hline Avusturya & 20.1 & 1.8 & 12.4 & 1.3 & 2.1 & 1.2 & 0.1 & 1.0 & 0.0 & 0.2 \\
\hline Polonya & 16.2 & 2.2 & 9.2 & 1.6 & 2.6 & 0.2 & 0.0 & 0.2 & 0.0 & 0.1 \\
\hline Portekiz & 17.1 & 1.4 & 11.5 & 1.7 & 1.0 & 0.7 & 0.2 & 0.3 & 0.0 & 0.4 \\
\hline
\end{tabular}

${ }^{38}$ Lowder, Bertini ve Croppenstedt, "Poverty, Social Protection and Agriculture", s.96.

${ }^{39}$ ILO, "World Social Protection Report 2017-19: Universal Social Protection to Achieve the Sustainable Development Goals". Geneva: ILO, 2017, s.iv. 


\begin{tabular}{|l|c|c|c|c|c|c|c|c|c|c|}
\hline Romanya & 11.6 & 1.1 & 8.6 & 0.1 & 1.2 & 0.1 & 0.0 & 0.1 & 0.0 & 0.5 \\
\hline Slovenya & 16.7 & 2.1 & 9.9 & 1.3 & 1.8 & 0.4 & 0.0 & 0.8 & 0.0 & 0.2 \\
\hline Slovakya & 14.3 & 3.1 & 7.7 & 0.8 & 1.0 & 0.2 & 0.0 & 0.2 & 0.0 & 1.3 \\
\hline Finlandiya & 24.1 & 3.1 & 13.6 & 0.7 & 3.0 & 1.9 & 9.6 & 1.0 & 0.0 & 0.3 \\
\hline İsveç & 19.5 & 3.7 & 10.5 & 0.2 & 2.5 & 1.2 & 0.3 & 1.1 & 0.0 & 0.0 \\
\hline İngiltere & 14.9 & 2.4 & 8.3 & 0.1 & 1.3 & 0.1 & 1.0 & 1.6 & 0.0 & 0.3 \\
\hline İzlanda & 9.9 & 3.2 & 3.1 & 0.0 & 2.1 & 0.5 & 0.4 & 0.3 & 0.0 & 0.3 \\
\hline Norveç & 19.1 & 6.6 & 7.1 & 0.2 & 3.2 & 0.4 & 0.1 & 0.9 & 0.0 & 0.4 \\
\hline İsviçre & 13.3 & 2.9 & 6.7 & 0.3 & 0.5 & 1.1 & 0.0 & 1.6 & 0.0 & 0.3 \\
\hline
\end{tabular}

Kaynak: Eurostat.

2018 yılında AB-27'de, sosyal koruma harcamaları GSYİH'nın \% 19,2'si, toplam harcamaların \% 41,2'si ve 2,591 milyar Avro olarak gerçekleşmiştir. Bu bölümdeki en önemli grup olan 'yaşlilık' (AB-27'de 2018'de GSYİH'nin \% 10,4'ü ve Euro bölgesinde GSYİH'nın \% 10,7'si) temelde emeklilik ödemeleriyle ilgilidir. Aynı durum, 2018 yılında AB-27 düzeyinde GSYİH’nın \% 1,5’i ve euro bölgesi düzeyinde GSYİH'nın \% 1,7'si düzeyinde olan toplam harcaman, 'hayatta kalanlar' için de geçerlidir.

Sosyal korumanın amacı evrensel bir sosyal koruma sağlamak mı yoksa en savunmasız kişilere ulaşmak mı? Ayrıca politika düzeyindeki kilit soru: masrafları kim ödeyecektir? Birleşmiş Milletler BM İnsan Hakları Yüksek Komiserliği için bir bilgilendirme notunda, Birleşmiş Milletlerin Gıda Hakkı Özel Raportörü Olivier de Schutter ve Birleşmiş Milletlerin Aşırı Yoksulluk ve İnsan Hakları Özel Raportörü Magdalena Sepúlveda, kalkınma modelinin "büyük oranda desteklediğini” savunmaktadır. ${ }^{40}$ Bir sosyal koruma planının uygulanması aslında özellikle yoksul ülkeler için büyük bir yatırımdır. Pek çok insanın sosyal korumadan çıkarılmasının nedeni yalnızca 'yoksul kişilerin çalışmaya teşvik edilmesi' gerekçesi ile değil, öncelikle finansal kaynakların etkinsiz bir şekilde tahsis edildiği basit gerçeğin bir sonucudur.

Bununla birlikte, az sayıdaki kişi, devletin sosyal koruma politikaları için düzenleyici çerçevenin oluşturulmasında ve programlarını finanse etmekte önemli bir role sahip olduğuna inanmaktadır. UNRISD raporu, evrensel sosyal koruma sağlanması, finansman sağlama, yönetme ve programları ve kurumları düzenlemede kilit sorumlulukları üstlenecek devlet gerektirdiğini ifade etmektedir. ${ }^{41}$ Ancak gerçeklik yoksul ülkelerdeki yoksul hane halklarının akraba, toplum ve dini kurumlar gibi devlet dışı kaynaklara dayandığını ve doğrudan devlet desteğinden nadiren fayda sağladığını göstermektedir. ${ }^{42}$

\section{Temel Tartışma Noktaları}

Başarılarına ve insani gelişmeye katkılarına rağmen, sosyal koruma her zaman yoğun eleştirilere maruz kalmıştır. Sosyal koruma politikaları, başlangıcından bu yana, genel ekonomik performans üzerinde olumsuz bir etkiye sahip olduğu için ekonomik gerekçelerle eleştirilmiştir. Eleştirmenler, sosyal koruma harcamaları-

\footnotetext{
${ }^{40}$ Olivier de Schutter ve Magdalena Sepúldeva, Underwriting the Poor: A Global Fund for Social Protection, Briefing Note Number 7, 2012, s.1.

${ }^{41}$ UNRISD, Combating Poverty and Inequality.

${ }^{42}$ Norton, Conway ve Foster, "Social Protection Concepts and Approaches: Implications for Policy and Practice in International Development", s.11.
} 
nın çok pahalı olduklarını ve kamu fonlarını tüketen ve diğer öncelikli alanlara yatırım yapma firsatlarını azaltan yük olduğunu iddia etmektedirler.

$\mathrm{Bu}$ arka plana karşı, herkes için temel sosyal koruma tabanlarının garanti altına alınması fikrine dayalı olarak birkaç teklif geliştirilmiştir. Aslında, 2012 yılında ILO, evrensel sosyal korumaya ulaşmak için bir tür rehber çerçeve oluşturan 202 sayılı Kararı (Sosyal Koruma Katları Tavsiyesi) onaylamıştır. Sosyal güvenlik için insan haklarını yeniden teyit eden tavsiye, temel gelir güvencesi ve yaşam döngüsü boyunca ihtiyacı olan herkes için temel sağlı hizmeti garantilerinden oluşan sosyal koruma tabanlarının bir önceliği olarak kurulmasını kapsamlı bir temel unsur olarak gerektirir. ${ }^{43} \mathrm{Bu}$ asgari sosyal koruma tabanını garanti altına alma mantığında, özellikle parasal geliri garanti altına almak açısından, dünya çapında iki unsur yayılmaktadır. Bunlardan biri Şartlı Nakit Transferleri (ŞNT) programlarıdır. Bu programlar, esas olarak gelir yoksulluğu sorunuyla yüzleşmek için araçlar olarak tasarlanarak kısa vadede gelir eksikliği, uzun vadede yoksulluğun nesiller arası yeniden üretimine son vermek ve kadınların ekonomik olarak güçlendirilmesini teşvik etme amacını taşımaktadır. İkincisi, bu programların çocukları ve ergenleri hedef almasına rağmen pratikte faydalar anneler tarafından alınmaktadır.

\section{Politika Tartışmaları}

Resmi sosyal koruma, büyük ölçüde kamu politikasıyla ilgilidir. Bazı azgelişmiş ülkelerde, kamu önlemleri önemli ölçüde dışarıdan finanse edildiğinden, karar vericilerin kamu eyleminin rolünü ve bunun içinde uluslararası yardımın rolünü tanımlamaları gerekir. Diğer bir deyişle, gelişmekte olan ülkelerin sık sık 'çifte bağımlılık' yani kamu tarafından finanse edilen müdahaleler ve yardım bağımlılığı ile ilgili endişelerle yüzleşmeleri gerekir. ${ }^{44}$

Sosyal koruma paketlerinin maliyetleri üzerine yapılan analizler, genel kanıya rağmen sosyal korumanın düşük gelirli ülkelerde bile karşılanabilir olduğu sonucuna varmaktadır. Yine de, sürdürülebilirlikle ilgili bazı kalıcı sorunlar var.

\section{Kurumsal Faktörler}

Sosyal koruma sistemlerinin unsurları, genellikle farklı sorumluluk ve hesap verebilirlik hatlarına sahip çok sayıda bakanlık arasında yayılarak yönetimde karmaşaya yol açar. Bu, çabaların tekrarlanmasına, kapsamda boşluklara ve zayıf kurumsal koordinasyona neden olabilir. Diğer durumlarda, programlar sınırlı bütçeye veya etkiye sahip tek bir bakanlık altında gruplandırılır. Faaliyetler arasında ise haritalama, değerlendirme, rasyonelleştirme, yeniden hedefleme, maliyetlendirme programları ve süreçlerin genel düzene sokulması ve koordinasyonu yer alır. ${ }^{45}$ Aslında tam da bu noktada, bir yandan öngörülebilirliğin artırılması ile diğer yandan kurumsal esneklik ihtiyacı arasında olası bir gerilim ortaya çıkmaktadır. Örneğin, öngörülebilirlik öncelikle uzun süreli programların kurumsallaştırılması yoluyla elde edilirse, bunların olası bir kriz sona erdiğinde azaltılması muhtemelen karmaşık olacaktır. Kısa vadede teknik ve politik olarak uygun olsalar da, bu programlar, küresel dalgalanmalara uygun olmayan olası istenmeyen uzun vadeli esnekliklere neden olabilir.

\footnotetext{
${ }^{43}$ ILO, Universal Social Protection for Human Dignity, Social Justice and Sustainable Development.

${ }^{44}$ Gentilini ve Omamo, "Social Protection 2.0", s.333.

${ }^{45}$ World Bank, "Social Protection in Pakistan: Managing Household Risks and Vulnerability". South Asia Region Report No. 35472-PK. Washington, DC., 2007.
} 


\section{Yeni Bir Sosyal Koruma Anlayışına Doğru}

Sosyal koruma kavramı, 1990’ların sonlarından bu yana birçok ülkede değişen yeni bir araştırma ve politika inisiyatifi düzeni ortaya çıkarmıştır: (1) gelişmekte olan ülkelerin refah rejimlerinin çalışmaları; (2) 2015 sonrası Sürdürülebilir Kalkınma Hedefleri gündeminde sosyal korumanın resmi olarak benimsenmesi; (3) Dünya Bankası ve DFID gibi büyük bağış̧̧ılar arasında evrensel kamu hizmeti fikrinin daha fazla kabul edilebilirliğidir. ${ }^{46}$

Bu çerçevede orta ve uzun vadede sosyal yardımların nasıl finanse edilebileceği merak konusudur. Filgueira ve arkadaşlarına göre evrensel bir sosyal koruma tabanı oluşturmak aslında o kadar da zor değildir. Çünkü 18 yaşın altındaki tüm çocukların, kayıt dişı çalışanların ve 65 yaşın üstündeki herkesin, temel ihtiyaçları karşılamak için aşırı yoksulluk düzeyinde yıllık bir gelir sağlamak, yalnızca bölgesel GSYİH’nın \% 5.4'üne denk gelmektedir. ${ }^{47}$ Bazı yoksul ülkeler için, özellikle Orta Amerika'da, çok taraflı yardım hayati önem taşımaktadır. Daha gelişmiş ülkeler için, böyle bir taban sağlamanın önündeki engeller mali veya teknik olmaktan çok politiktir. Sürdürülemez borçlanmayı masadan kaldırırsak zorluk, hükümet harcamalarını daha adil ve verimli yollarla yeniden yönlendirme ve çoğu elitin dünyadaki emsallerine kıyasla çok daha az vergi ödediği bir bölgede vergi yükünü artırma şeklinde geliyor. Belki de bu kriz, bu politika önerilerini Latin Amerika ülkelerinin siyasi gündemlerinde daha önce hiç olmadığı kadar ön plana çıkarmak için bir fırsat sunmaktadir. ${ }^{48}$

ILO ve Dünya Bankası'nın ortak hedefi, evrensel sosyal koruma sağlayabilecek ülkelerin sayısını artırmak, ülkeleri evrensel ve sürdürülebilir sosyal koruma sistemleri tasarlamak ve uygulamak için desteklemektir. Hedef, ILO'nun istek uyandıran unsurlarını ve Dünya Bankası'nın ortak vizyonunu kabul etmekte ve bu vizyona ulaşmanın yollarının sosyal korumanın ilerici veya anında gerçekleştirilmesinin yanı sıra elde edilen ilerlemede hiçbir gerilemenin olmamasını sağlamak yoluyla olduğunu kabul etmektedir. Hedef, ülkelerin yaşam döngüsü boyunca evrensel koruma sağlayan kapsamlı sistemler geliştirmesi ve sosyal koruma sistemlerinin karşılanabilir, verimli, etkili ve eşitlikçi olduğuna dair yeterli kanıt olması durumunda, daha fazla ülkenin bu sistemleri ulusal kalkınma stratejilerinin bir parçası olarak benimseyeceğini kabul etmektedir.

Ülkeler, evrensel sosyal koruma kapsamına ulaşmak için geniş seçeneklere sahiptir. Genel olarak evrensellik, katkı sağlayan programları birleştirerek elde edilir. Örneğin, Çin Halk Cumhuriyeti, kırsal alanlarda sosyal sigortayı emekli maaşlarıyla tamamlayarak neredeyse evrensel emekli maaşları elde etmiştir. Bolivya gibi diğer ülkeler, tüm yaşlılara vergiyle finanse edilen evrensel faydalar sağlamaktadır. Bazı ülkeler kademeli ve aşamalı gerçekleştirmeyi seçerken, diğerleri acil evrensel kapsamı tercih etmektedir. Açıktır ki, cesur uzun vadeli sosyal koruma taahhütleri düşük kapasiteli bağlamlarda kurumsallaştırıldığında konu daha da tartışmalı hale

\footnotetext{
${ }^{46}$ Rana Jawad, A New Era for Social Protection Analysis in LMICs? A Critical Social Policy Perspective from the Middle East and North Africa Region (MENA), World Development, 123 (2019), s.12

${ }^{47}$ Fernando Filgueira, Luis Miguel Galindo, Cecilia Giambruno, ve Merike Blofield, América Latina ante la crisis del COVID19: vulnerabilidad socio-económica y respuesta social, ECLAC-Social Policy Series Series, Santiago: CEPAL/ECLAC, 2020, s.7.

${ }^{48}$ GIGA Focus Lateinamerika, 7/10 (2020), Social Policy Responses to the COVID-19 Crisis and the Road Ahead özel sayısı. https://www.giga-hamburg.de/en/publications/21606516-social-policy-responses-covid19-crisis-road-ahead/.
} 
gelmektedir. Gelecekteki kurumsal yenilikler, esneklik ve öngörülebilirliğin nasıl birleştirileceğini önceden daha iyi keşfetmelidir. ${ }^{49}$

\section{Sonuç}

2000'lerden beri, sosyal koruma, uluslararası kalkınma politikası çevrelerinde meşruiyet kazanmış ve gittikçe gelişen bir çizgide gelişimini sürdürmektedir. ILO'nun ücretli işgücü dışındaki nüfusu koruma girişimi Dünya Bankası'nın bir zamanlar münhasıran neoliberal görünümünden geri adımını ve sözde 'üçüncü yolu desteklemek için DfID ve UNDP gibi kalkınma örgütlerinin müdahalelerini yansıtıyor. Burada sosyal koruma hem temel bir hak hem de sosyal bir yatırım olarak kabul edilir. Bununla birlikte, bu değişiklikler pozisyonların bariz bir şekilde hizalandığına işaret ederken, gerçek bir uluslararası fikir birliği hala belirsizliğini korumaktadır. Kamu ve özel sektörün göreli önemi, evrenselliğe karşı hedeflemenin etkinliği ve yardıma koşullu ve koşulsuz erişimin esası gibi konularda güçlü farklılıklar sürmektedir.

Küresel sosyal koruma seviyesi tüm zamanların en yüksek seviyesindedir ve kapsam artmaya devam etmektedir. Küresel nüfusun çoğu ya hükümetleri bunu sağlamadığı için ya da kapsamın genellikle bulunmadığı kayıt dışı sektörde çalıştıkları için uygun bir şekilde sosyal koruma kapsamında değildir. Sosyal koruma programlarının geliştirilmesi ve genişletilmesi maliyetli bir meseledir. Bu nedenle, onları amaca uygun hale getirmek, finansal ve toplumsal sürdürülebilirlikleri için çok önemlidir.

Sonuç olarak, kapsamlı sosyal koruma sistemleri farklı ülkelerde çok çeşitli ve karmaşık olma eğilimindedir. Sigortaların, programların, yasaların ve düzenlemelerin, idari prosedürlerin ve bürokratik kararların artan çeşitliliği ve karmaşıklığı, genellikle bir tarafta sosyal yönetim ile sosyal hizmet talep eden vatandaşlar ve diğer tarafta yardım talep eden kişiler arasında bağlantı olarak sosyal hizmetleri gerektirir. Bu yüzden hükümetler ve uluslararası kuruluşlar, bu politikaları teşvik etmeli ve sosyal yardımları, yoksulluğu azaltmanın ve sosyal dönüşümün etkili bir aracı olarak takdir etmelerini sağlamak için mevcut programların desteklemelidir.

\section{Kaynakça}

Alderman, Harold. "Safety Nets Can Help Address The Risks to Nutrition from Increasing Climate Variability”. Journal of Nutrition. 140/1 (2010): 148-152.

Barrientos, Armando ve David Hulme. "Social Protection for the Poor and Poorest in Developing Countries: Reflections on a Quiet Revolution Commentary". Oxford Development Studies. 37/4 (2009): 439-456.

Barrientos, Armando. "Social Protection and Poverty". International Journal of Social Welfare. (Special Issue: Social Policy and Poverty). 20/3 (2011): 240-249.

Barrientos, Armando ve David Hulme. Social Protection for the Poor and the Poorest: Concept, Policies and Politics, Basingstoke: Palgrave Macmillan, 2008.

Bonilla-Garcia, A. ve J. V. Gruat. Social Protection: A Life Cycle Continuum Investment for Social Justice, Poverty Reduction and Sustainable Development. Geneva: ILO, 2003.

\footnotetext{
${ }^{49}$ Harold Alderman, "Safety Nets Can Help Address the Risks to Nutrition from Increasing Climate Variability”, Journal of Nutrition, 140/1 (2010), s.149.
} 
Conway, Tim, Arjan de Haan ve Andy Norton. "Social Protection: New Directions of Donor Agencies". Research Report. London: Overseas Development Institute (ODI), 2000.

Corina, Rodríguez Enríquez. "Current Challenges and Debates on Social Protection in the Global South". Development Alternatives with Women for a New Era (DAWN) sitesi. March 19, 2020. https://dawnnet.org/2020/03/socialprotection-in-the-global-south/.

Devereux, Stephen. "Building Social Protection System in Southern Africa". Background Paper to the European Report on Development, Center for Protection, Institute of Development Studies, Brighton, 2010.

Drolet, Julie L. (der.). Social Development and Social Work Perspectives on Social Protection. London: Routledge, 2016.

Filgueira, Fernando, Luis Miguel Galindo, Cecilia Giambruno ve Merike Blofield. América Latina ante la Crisis del COVID19: Vulnerabilidad Socio-económica y Respuesta Social. ECLAC-Social Policy Series Series, Santiago: CEPAL/ECLAC, 2020.

Fukuda-Parr, Sakiko. "Millennium Development Goal 8: Indicators for International Human Rights Obligations?" Human Rights Quarterly. 28 (2006): 966-997.

Gentilini, Ugo, Steven Were Omamo. "Social Protection 2.0: Exploring Issues, Evidence and Debates in a Globalizing World". Food Policy. 36/3 (2011): 329340.

Hanlon, J. Barrientos and David A. Hulme. Just Give Money To The Poor: The Development Revolution from the Global South. Sterling. Vancouver, USA: Kumarian Press, 2010.

Hickey, Sam. "The Politics of Social Protection: What Do We Get From A 'Social Contract' Approach?” Canadian Journal of Development. 32/4 (2011): 426-438. 